\title{
REFLECTIONS ON THE CONTRIBUTIONS OF ADRIAN EVANS
}

\section{Jeff Giddings,}

\section{Associate Dean (Experiential}

\section{Education), Monash Law Faculty}

My early memories of Adrian Evans are

from community legal centre national conferences in the late-1980s. He was well established at the La Trobe SRC Legal Service when I started at Fitzroy

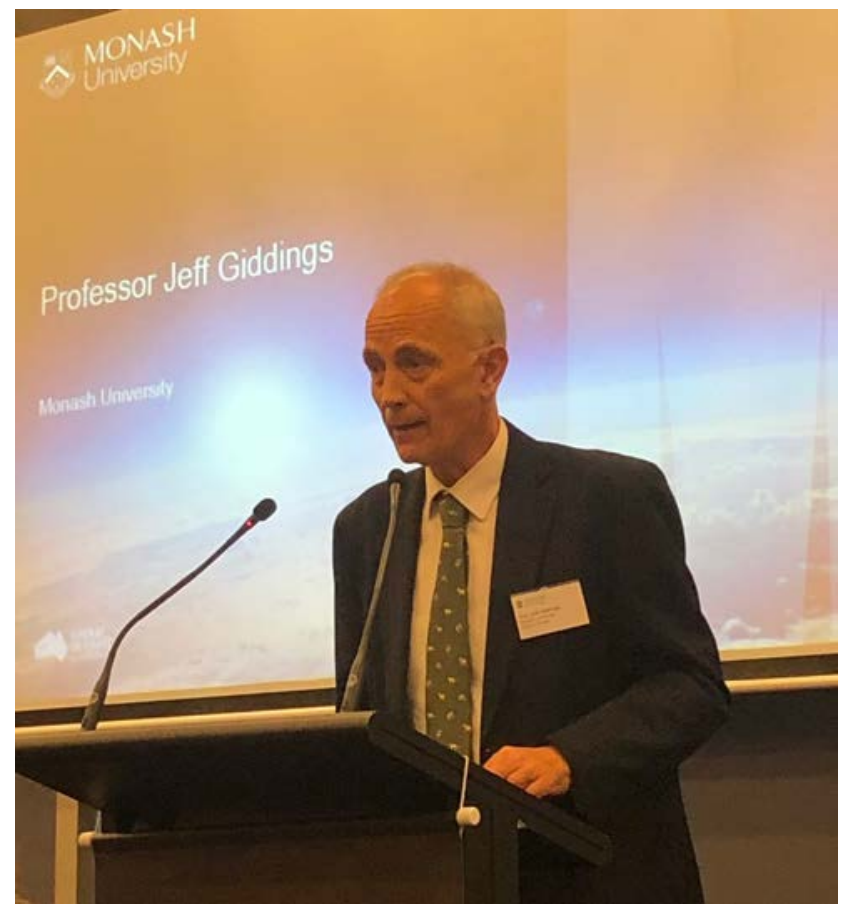

Legal Service. Adrian was the quiet achiever with responsibility for the Professional Indemnity Insurance cross-checks that all CLCs needed to complete. Adrian arrived at Monash Law Faculty in 1988, taking on the role of Director of the (then) Springvale Legal Service (now the Springvale Monash Legal Service). In taking over this role from Simon Smith, Adrian had a hard act to follow. My respect for both Simon and Adrian has continued to grow over the last 30 years.

As a student then volunteer at Springvale Legal Service (SLS), I saw how Simon had shaped the maverick culture of SLS, driving progress on a wide range of issues and spearheading the fundraising that enabled SLS to build new premises at 5 Osborne Avenue. With the support of senior Monash clinicians, Sue Campbell and Guy Powles, 
Adrian developed a more structured approach to establishing the priorities of both SLS as a service and the Monash clinical program more generally. ${ }^{1}$

\section{Springvale Legal Service}

A key focus of Adrian's early casework at SLS involved continuing Simon's work on claims against a local solicitor, Peter C Neil. Former clients of Neil's came to SLS seeking advice regarding proceedings issued against them by Neil, seeking payment of legal fees for work done years earlier. ${ }^{2}$ I remember Adrian telling me that this work persuaded him that developing socially responsible lawyers required the community 'to deal with lawyers who are rogues.' He rightly called out the failure of the Law Institute of Victoria to hold lawyers to the standards expected by the public. 'We couldn't be coherent as a clinical program unless we were addressing both ends of the problem.' $^{3}$

Adrian's approach to lawyering provided a powerful example to his students and colleagues. My Monash clinical colleague, Ross Hyams shared the following insight into Adrian's time as Director of SLS:

During Adrian's time as Director of SLS, he always bore such a sense of social responsibility that he felt that he was basically unable to turn a client in need away. This was back in the days before the legal service put a cap on how many clients could be seen on any given day. So, having dealt with the rush of 15-20 clients in the mornings that he was on session, any client who wandered in for the rest of the day

\footnotetext{
${ }^{1} \mathrm{~J}$ eff Giddings, Promoting J ustice Through Clinical Legal Education, J ustice Press, 2013, Chapter 6.

$2 /$ bid, 188.

3 /bid, 188-189.
} 
would always be seen. This sometimes resulted in another 5-10 clients in the afternoon, rolling into the night. It was well known amongst the students that if you were assigned to Adrian's client session day that you would work and work hard!

Adrian was the catalyst for moves by the Monash clinical program to extend student involvement in community development activities. This involved focused group work with clearly articulated objectives and was in keeping with Adrian's view that 'Clinical legal education can only reach its full social and educative potential in a community environment' ${ }^{4}$

\section{Calling Canberra!}

There's a great story about Adrian sending a letter of congratulations to the Shadow Attorney General after an election, congratulating him (wrongly) on becoming the first law officer in the jurisdiction. This anecdote was no doubt a one-off occurrence as Adrian has generally been very effective in balancing 'big picture' vision with command of the detail.

Adrian was closely involved in efforts to raise the profile of clinical legal education with successive federal governments in the 1990s. ${ }^{5}$ Monash was recognised for its leadership role in Australian clinical legal education through the arrangements made for its clinicians, including Adrian, to mentor staff involved in establishing the new clinical program at Murdoch University in 1996. ${ }^{6}$ The 1998 federal budget announced funding for the Commonwealth Attorney-General's Department to support

\footnotetext{
${ }^{4}$ Adrian Evans, 'Developing Socially Responsible lawyers' (1990) 15(5) Legal Service Bulletin 218, 219.

${ }^{5}$ Giddings, note $1,191$.

6 / bid, Chapter Nine, footnotes $68-73$ for further details.
} 
university clinical legal education programs and, early in 1999, Monash was one of the four law schools that secured funding, establishing the Family Law Assistance Program (FLAP) supporting family law clients without legal representation. ${ }^{7}$

In 1996, Adrian wrote about the establishment of a multi-disciplinary clinic addressing the complex issues faced by victims of sexual assault. ${ }^{8}$ Having observed similar clinics overseas, he approached Carolyn Worth (Co-ordinator of the South East Centre Against Sexual Assault (SECASA) about the development of a pilot program. This advanced placement became an ongoing part of the Monash clinical program. ${ }^{9}$ It provided students who had completed the general clinic with opportunities to further develop their skills and 'gain a deeper understanding of the operation of the legal system through immersion in a particular area of law'. ${ }^{10}$

\section{The Australian Clinical Best Practices Project}

Monash was the lead institution for a collaborative project to develop Best Practices in Australian Clinical Legal Education in 2011-2012. With funding from the Australian Government Office for Learning and Teaching, clinicians from 6 law schools (Anna Cody, Anna Copeland, Adrian Evans, Mary Anne Noone, Simon Rice and myself)

\footnotetext{
${ }^{7}$ J eff Giddings, The Commonwealth Discovers Clinical Legal Education' (1998) 23(3) Alternative Law Journal 140. In relation to the operation of the FLAP, see Susan Campbell and Alan Ray, 'Specialist Clinical Legal Education: An Australian Model' (2003) 3 International Journal of Clinical Legal Education 67.

${ }^{8}$ Adrian Evans, 'Specialised Clinical Legal Education Begins in Australia' (1996) 21(2) Alternative Law Journal 79.

${ }^{9}$ Fay Gertner and Carolyn Worth, 'Compensating Sexual Assault Victims: The Development of a Specialist Legal Clinic' in Bronwyn Naylor and Ross Hyams (eds), Innovation in Clinical Legal Education: Educating Lawyers for the Future (2007) 53.

10 Ibid.
} 
developed resources to support effective practices in clinical legal education. ${ }^{11}$ Adrian was the leader of this ambitious project to develop standards or recommended practices ("Best Practices") for effective clinical legal education in Australia both to improve the delivery of clinical legal education and to assist in the renewal of University law curricula.

Adrian had to adjust his approach to leading the Best Practices Project. It became clear early on that he had hoped we would develop a set of standards to be met by all clinical programs. Other members of the team (me included) saw our aim as providing guidance through the identification of effective practices that programs should consider adopting. I could see the way that it was a challenge for Adrian to take this different approach and I was impressed that he managed to do so. It became a consensus-driven project with every team member having lots of ideas and plenty to say. Hard work but productive. At one team meeting, Adrian asked ‘When are we going to get to my pet thing?'. I've enjoyed using that phrase in subsequent discussions.

We developed a comprehensive set of best practices, organised under seven themes comprising Course Design, Law in Context in a Clinical Setting, Reflective Student Learning, Assessment, Supervision, Staff and Infrastructure. These best practices were endorsed by the Council of Australian Law Deans in November, 2012. ${ }^{12}$ The project

\footnotetext{
${ }^{11}$ See Best Practices: Australian Clinical Legal Education: The Final Report of the Project, Strengthening Australian Legal Education by Integrating Clinical Experiences: Identifying and Supporting Effective Practices. Accessible at https://ltr.edu.au/

12 Ibid, 7.
} 
also generated a jointly-authored book, Australian Clinical Legal Education. ${ }^{13}$ Adrian's role was once again important here as we moved to share more of what we had learnt through the project.

\section{The Monash Clinical Guarantee}

Monash is in the midst of a major expansion of its clinical legal education program. We have introduced a Clinical Guarantee, assuring every law student that they will have an opportunity to participate in our clinical program if they so choose. We are the first Australian law school to do so and you can imagine that doing so has involved a range of opportunities and challenges. Monash is seeking to develop approaches to foster legal professionals and thinkers who will be adept in emerging local and global professional contexts. The clinical program has been identified as having an important role to play in preparing students for the world of future legal work.

The Faculty is implementing the Guarantee across 2018-2020. This involves a very substantial increase in the numbers of students able to participate in a clinical experience. We expect that by the end of 2020 , more than $80 \%$ of students will take up this opportunity to participate before they complete their degree. We are expanding existing clinics as well as building a range of new partnerships and collaborations. 287 students were able to participate in a clinical unit in 2018 and 385 are projected to participate in 2019. This expansion in participation has been enabled by strong support from Monash University and its Law Faculty with extension of one of its key

\footnotetext{
${ }^{13}$ Adrian Evans, Anna Cody, Anna Copeland, J eff Giddings, Peter J oy, Mary Anne Noone \& Simon Rice Australian Clinical Legal Education, ANU Press, 2017.
} 
clinic sites, Monash Law Clinics - Clayton, and the opening of a new clinic site in the Melbourne CBD, Monash Law Clinics - Melbourne.

Adrian Evans was a key figure in the development of the Clinical Guarantee as an idea once it was suggested by Peter Joy when he visited Monash Law Faculty in 2016. Having now been given the opportunity to steer this ambitious project, I want to thank Adrian for having the 'can do' attitude and vision to pursue an ambitious project like the Clinical Guarantee. Adrian had the good sense to work closely with our Dean, Bryan Horrigan and the (then) Faculty Manager, Jane Prior, in developing the initial proposal. Since then, he has had the strength not to try to be a back seat driver. He has helped Melissa Fletcher and me in our efforts to juggle an array of interests and agendas as we develop and implement this worthy project. 